\title{
Salinity induced apoptosis in food spoilage yeast Zygosaccharomyces bisporus
}

\author{
*Sharma, A., and Sharma, S. C. \\ Department of Biochemistry, Panjab University, Chandigarh, 160014, India \\ *Correspondence to: akshya.msdn@gmail.com; 9915596237
}

\begin{abstract}
:
Background: Food spoilage is one of the most serious challenges in agriculture, and food and beverage industry, which can lead to worldwide food economic loss. The crucial organoleptic species, Zygosaccharomyces bisporus, is a highly resistant yeast fungus that can escape industrial quality check. They survive high salt environments by undergoing immediate programmed cell death (PCD), which plays an important role in mediating adaptive responses to adverse environmental conditions. Production of reactive oxygen species (ROS) prompted by salt stress is an early event in apoptosis, which in later stage is associated with prime genomic degradation.

Methodology: In this study, the tolerance mechanism to salt of $Z$. bisporus MTCC 4801 cells was investigated by serial dilution of exponential growth phase of the cells in $1.0 \mathrm{M}$ sodium chloride $(\mathrm{NaCl})$ as salt stressor, and spotting on Yeast Peptone Dextrose Agar (YPDA) plates with incubation at $28^{\circ} \mathrm{C}$ for growth assessment and colony count. Transmission electron microscopy (TEM) was used to demonstrate characteristic ultrastructural hallmark features of apoptosis on Z. bisporus cells exposed to $1.0 \mathrm{M} \mathrm{NaCl}$ at three different stress interval periods; 60,90, and 120 minutes.

Results: Growth of $Z$. bisporus cells on the YPDA plates was observed after 16 hours incubation period. Comparing the growths, $Z$. bisporus tolerated salt concentration below $1.0 \mathrm{M} \mathrm{NaCl}$ but no growth was observed at $1.0 \mathrm{M} \mathrm{NaCl}$ concentration indicating $1.0 \mathrm{M} \mathrm{NaCl}$ to be limiting concentration for $Z$. bisporus growth. TEM analyses showed that treatment of $Z$. bisporus with $1.0 \mathrm{M} \mathrm{NaCl}$ resulted in nuclear and cytoplasmic condensation, membrane blabbing, cytoskeletal distortion, and formation of apoptotic bodies. However, on prolonged stress span (90 and 120 minutes), the fungal cells were able to osmoadapt and repaired the damaged cells, resulting in lowering of the apoptotic ratio.

Conclusion: These qualitative analyses contribute more insights regarding stress adaptive mechanisms in moderately halotolerant food spoilage yeast.
\end{abstract}

Key words: Apoptosis; salt stress; food spoilage yeast; TEM; cell survival

Received April 20, 2019; Revised July 30, 2019; Accepted August 3, 2019

Copyright 2020 AJCEM Open Access. This article is licensed and distributed under the terms of the Creative Commons Attrition 4.0 International License (http://creativecommmons.org/licenses/by/4.0), which permits unrestricted use, distribution and reproduction in any medium, provided credit is given to the original author(s) and the source.

\section{Apoptose induite par la salinité chez la levure altérant les aliments Zygosaccharomyces bisporus}

\author{
*Sharma, A., et Sharma, S. C.
}

Département de biochimie, Université Panjab, Chandigarh, 160014, Inde

*Correspondance à: akshya.msdn@gmail.com; 9915596237

\begin{abstract}
Abstrait:
Contexte: La détérioration des aliments est I'un des problèmes les plus graves dans l'agriculture et l'industrie de I'alimentation et des boissons, ce qui peut entraîner des pertes économiques dans le monde de l'alimentation. L'espèce organoleptique cruciale, Zygosaccharomyces bisporus, est un champignon de levure très résistant qui
\end{abstract}


peut échapper au contrôle de la qualité industrielle. Ils survivent aux environnements riches en sel en subissant une mort cellulaire programmée (PCD) immédiate, qui joue un rôle important dans la médiation des réponses adaptatives aux conditions environnementales défavorables. La production d'espèces réactives de l'oxygène (ROS) provoquées par le stress salin est un événement précoce de l'apoptose, qui est associé à un stade avancé de dégradation génomique.

Méthodologie: Dans cette étude, le mécanisme de tolérance au sel des cellules MTCC 4801 de Z. bisporus a été étudié par dilution en série de la phase de croissance exponentielle des cellules dans du chlorure de sodium ( $\mathrm{NaCl}$ ) à $1,0 \mathrm{M}$ en tant que facteur de stress salin, et par repérage sur la gélose de levure peptone Dextrose Agar (YPDA) avec incubation à $28^{\circ} \mathrm{C}$ pour l'évaluation de la croissance et le nombre de colonies. La microscopie électronique à transmission (MET) a été utilisée pour démontrer les caractéristiques de l'apoptose ultrastructurales des cellules de Z. bisporus exposées à $1,0 \mathrm{M}$ de $\mathrm{NaCl}$ à trois périodes d'intervalle de stress différentes; 60,90 et 120 minutes Résultats: La croissance des cellules de $Z$. bisporus sur les plaques de YPDA a été observée après une période d'incubation de 16 heures. En comparant les croissances, une concentration en sel tolérée par Z. bisporus inférieure à $1,0 \mathrm{M}$ de $\mathrm{NaCl}$, mais aucune croissance n'a été observée à une concentration de $1,0 \mathrm{M}$ en $\mathrm{NaCl}$, ce qui indique que $\mathrm{NaCl} 1,0 \mathrm{M}$ était la concentration limite pour $Z$. bisporus croissance. Les analyses TEM ont montré que le traitement de $Z$. bisporus avec $1,0 \mathrm{M}$ de $\mathrm{NaCl}$ entraînait une condensation nucléaire et cytoplasmique, un blabbing membranaire, une distorsion cytosquelettique et la formation de corps apoptotiques. Cependant, sur une période de stress prolongée (90 et 120 minutes), les cellules fongiques ont pu s'osmoadapter et ont réparé les cellules endommagées, ce qui a entraîné une diminution du rapport apoptotique.

Conclusion: ces analyses qualitatives apportent davantage d'informations sur les mécanismes d'adaptation au stress de la levure altérante modérément halotolérante.

Mots clés: apoptose; stress salin; levure d'altération des aliments; TEM; survie cellulaire

\section{Introduction:}

Despite satisfactory sanitation practices, large proportions of processed foods such as juices, pickles, jams and beverages are lost to due to spoilage by microbial contamination such as bacteria and yeasts. This has the potential to cause serious health hazards and substantial economic loss to food and beverage industries. Although, bacteria have extensively been studied for the evolved and conserved halotolerant mechanisms, yeasts have received more attention as key players responsible for food deterioration and spoilage. Among these, the major problematic genus Zygosaccharomyces, notably Z. bisporus, is typically osmotolerant and moderately halotolerant which ensures its remarkable survival in high salinity, a unique adaptation of Z. bisporus (1-4).

Salinity produces osmotic stress by decreasing the chemical activity of water and loss of turgor pressure, and ionic stress by cellular accumulation of high salt concentration (5-6). Under such conditions, strong plasma membrane depolarization due to $\mathrm{Na}^{+}$uptake favors $\mathrm{K}^{+}$efflux via depolarization-activated outward-rectifying $\mathrm{K}^{+}$TOK1 channels. The resultant elevated cytoplasmic $\mathrm{Na}^{+} / \mathrm{K}^{+}$ratio and osmotic stress induces mitochondrial oxidative burst which is known to be crucial for triggering the complex apoptotic cascade in stressed cells (7-9). As the wobbled redox status implicates over production of oxygen radicals $\left(\mathrm{HO}, \cdot \mathrm{O}_{2}{ }^{-}, \mathrm{H}_{2} \mathrm{O}_{2}\right)$, the predominant death signaling molecule in stimulating baxlinked ancestral apoptotic pathway, shorten the chronological life span (CLS) of yeast (911). A number of studies on evaluation of salt induced osmotic stress in yeasts have focused on cell physiology, morphology and genetic of the networks of cell division inhibition, decreased cell vitality, DNA damage, and increased cell death particularly due to apoptosis.

Programmed cell death (PCD) is widely associated with characteristic hallmark features such as nuclear fragmentation, chromatin condensation, cell shrinkage, and cytoplasmic condensation with clustering of apoptotic bodies (12-16). Although cytoplasmic condensation occurs, typical changes in the nucleus provide the most important means of identifying apoptosis $(13,14)$. Previous studies on Zygosaccharomyces rouxii, Debaryomyces nepalensis, Cryptococcus laurentii and other halotolerant fungi species had described physiological mechanisms underlying extreme salt tolerance in relation to apoptosis $(17,18)$, even as the capacity of these halotolerant food spoilage yeasts, to survive, grow, and metabolize actively under such hyperosmotic challenged conditions is essentially an important study in food industry.

In particular, identification of plausible mechanisms and physiological responses that shape the halostress response downlinks in Zygosaccharomyces food spoilage yeasts are crucial. However, the cellular mechanisms of salt injury in these yeasts, and the early events during induction of PCD by salt stress are scarcely known. Hence, this research was conducted to study the effects of salt stress on induction of PCD by determining cyto- 
morphological response of a moderately halotolerant yeast, $Z$. bisporus in an experimental model.

\section{Materials and Methods:}

Inoculum preparation \& culture of yeast strain The yeast strain $Z$. bisporus MTCC 4801 used in this study was procured from the Department of Biotechnology, Himachal Pradesh University, Shimla, India, and maintained at $4^{\circ} \mathrm{C}$ on pre autoclaved Yeast Peptone Dextrose Agar plates containing (w/v) $2 \%$ dextrose, $1 \%$ yeast extract, $2 \%$ peptone, and $2 \%$ agar. Cells were first grown on agar plates ( $\mathrm{pH} 5.5$ ) and incubated at $28^{\circ} \mathrm{C}$ for 48 hours. One loopful of the growth on the plate was transferred to $10 \mathrm{~mL}$ Yeast Peptone Dextrose (YPD) medium for inoculum preparation at incubated at $28^{\circ} \mathrm{C}$ for 16 hours at $200 \mathrm{rpm}$ in a rotary shaker. Cell growth was measured as an increase in optical density to $\sim 0.5$ (mid log phase cells) at $600 \mathrm{~nm}$ with UV spectrophotometer (1800 Shimadzu, Japan). From this pre-culture, $1.0 \%(\mathrm{v} / \mathrm{v})$ of inoculum containing $0.7 \times 10^{6}$ cells $/ \mathrm{ml}$ was transferred to YPD medium in Erlenmeyer flasks under similar growth conditions to obtain exponential phase yeast cells.

\section{Stress treatment of yeast strain}

In order to determine salt stress response, the cells survival, of exponentially growing yeast cells were serially diluted $\left(10^{5}\right.$ factor) in 1.0M sodium chloride stressor, spotted on YPD agar plate, and incubated at $28^{\circ} \mathrm{C}$ for 48 hours. Cultures that yielded colonies of $Z$. bisporus were counted and further analyzed according to standard microbiological procedures (18).

\section{Transmission electron microscopy examination of yeast strains}

Yeast cells in exponential growth phase were exposed to $1.0 \mathrm{M} \mathrm{NaCl}$, and incubated at $28^{\circ} \mathrm{C}$ in a rotary shaker $(200 \mathrm{rpm})$ for periods of 60,90 and 120 minutes. Both control (without stress exposure) and salt $(\mathrm{NaCl})$ treated yeast cells at three different time intervals were first fixed in $3.0 \%$ glutaraldehyde in Sorensen's phosphate buffer $(\mathrm{pH} 7.2)$ for $4-6$ hours at $4^{\circ} \mathrm{C}$ and rinsed twice with same buffer for 15 minutes. This was followed by secondary fixation with $1.0 \%$ Osmium tetroxide in Millonin's phosphate buffer $(\mathrm{pH} 7.2)$ for 90 minutes at $4^{\circ} \mathrm{C}$. The cells were again rinsed twice in Millonin's buffer for 15 minutes and dehydrated using increasing alcohol concentrations of $70 \%$,
$90 \%$, and $100 \%$ at room temperature, followed by rinsing in propylene oxide once for 15 minutes on the rotator for complete dehydration. The fixed specimens were then put in an epon mixture of $50 \%$ propylene oxide and $50 \%$ resin for at least 2 hours or overnight at room temperature before embedding in Taab-812 embedding medium.

Ultrathin sections of $60 \mathrm{~nm}$ thickness were cut on Leica EM UC-6 ultramicrotome (Leica Mikrosysteme $\mathrm{GmbH}$, Wien, Austria) and taken on Nickel grids. The sections were stained with uranyl acetate and lead citrate and examined at $80 \mathrm{kV}$ accelerating voltage Transmission Electron Microscope (JEM-1400 Plus, JEOL, Tokyo, Japan) equipped with XR81M-B Camera (Advanced Microscopy Techniques Corp, Woburn, MA, United States). Digital electron micrographs were obtained using AMT Image Capture Engine V602 software (Advanced Microscopy Techniques Corp, Woburn, MA, United States) with resolution of $500 \mathrm{~nm}$ and magnification power of $8000 \times$ (19).

\section{Results:}

\section{Effect of salt on growth of $Z$. bisporus}

Growth of the yeast cells on YPD medium supplemented with salt concentration of $1.0 \mathrm{M} \mathrm{NaCl}$ was observed after 16 hours incubation period by spotting assay. Comparing the growths, $Z$. bisporus tolerated salt concentration below $1.0 \mathrm{M} \mathrm{NaCl}$, but no growth was observed at $1.0 \mathrm{M} \mathrm{NaCl}$ concentration indicating $1.0 \mathrm{M} \mathrm{NaCl}$ to be limiting concentration for $Z$. bisporus growth. In the control (without $\mathrm{NaCl}$ ), maximum cell growth was observed (Fig 1.).

\section{Morphological analysis by TEM}

The apoptotic cells observed under transmission electron microscope exposed to $1.0 \mathrm{M} \mathrm{NaCl}$ at different stress intervals, established characteristic ultrastructure features known to be hallmarks of apoptosis (Fig 2). Yeast cells without salt stress treatment (control) were assessed along with cells treated with $1.0 \mathrm{M} \mathrm{NaCl}$ at three different stress imposition time intervals. The control cell exhibited characteristic ultrastructural morphology of a normal cell with uniform nucleus composed of regular dispersed chromatin and two nucleoli, and cytoplasm rich in rough endoplasmic reticulum (filled with ribosomes, polyribosomes), and mitochondria. The well-developed Golgi complex was located in the cytoplasm in perinuclear areas, and scarce, dense bodies and occasional 
autolysosomes were present in the cytoplasm (Fig 2: A).

Cytological observations in cells exposed to $1.0 \mathrm{M} \mathrm{NaCl}$ for 60 minutes included deeply invaginated, irregular nucleus with dense chromatin margination along the nuclear envelope and nuclear condensation (pyknosis), nuclear fragmentation (multi-nucleation), cytoplasmic extrusion, cell shrinkage, abnormalities of mitochondrial cristae (ruptured and condensed), cell membrane blabbing, holes and formation of apoptotic bodies, increased cellular granularities (dark condensed cytoplasm), and dilated nuclear membranes. The cells exhibited intense vacuolization filled with heavy granulated electron dense materials (Fig 2: B, C).

Cells exposed to stress for 90 minutes (Fig 2: D, E) and 120 minutes (Fig 2: F, G) showed low toxicity to both stress phases compared to control (Fig 2: A). Stress exposure for 120 minutes produced least toxicity compared to 90 and 60 minutes. These features collectively suggest that $\mathrm{NaCl}$-treated $Z$. bisporus demonstrated apoptotic-like cell death (ALCD) mechanism.
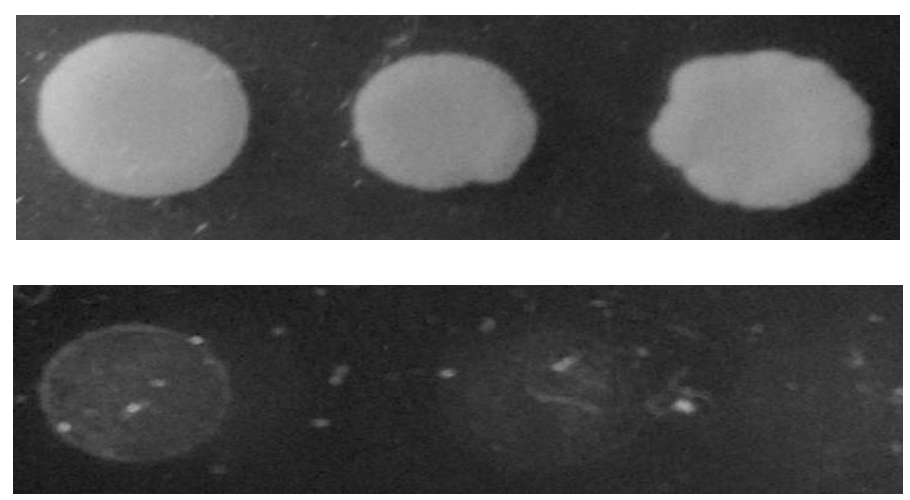

Fig 1: Serial-dilution (SD) colony spotting assay for Zygosaccharomyces bisporus sensitivity to $\mathrm{NaCl}$ in representative control (upper panel) and stressed (lower panel) cells on Yeast Peptone Dextrose Agar (YPDA) plates
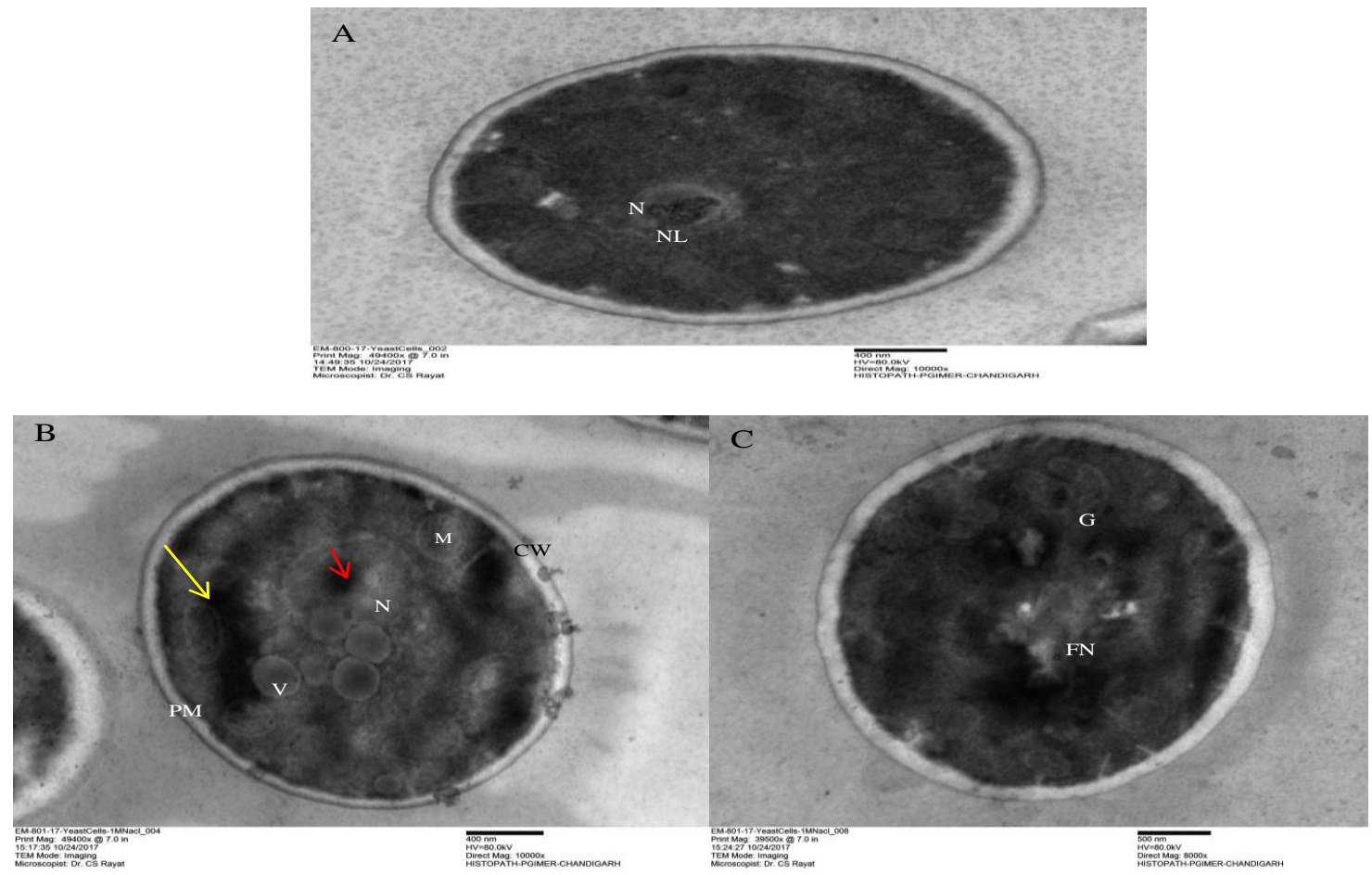

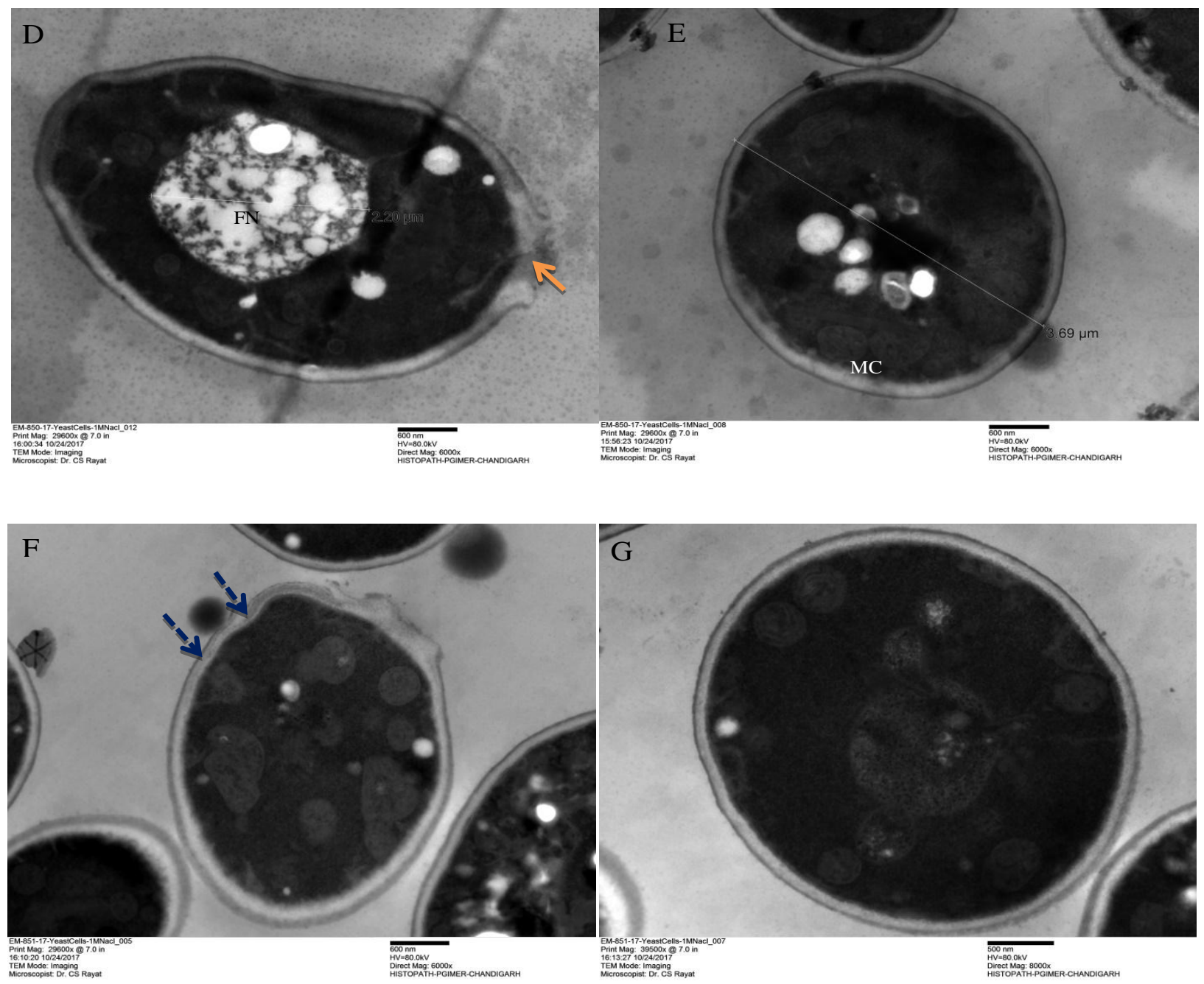

Fig 2: Transmission electron microscopy analysis (TEM) was performed to detect autophagic and apoptotic structures in; Control (A); $1.0 \mathrm{M} \mathrm{NaCl}$ treated cells for 60 minutes $(B, C) ; 1.0 \mathrm{M} \mathrm{NaCl}$ treated cells for 90 minutes $(\mathrm{D}, \mathrm{E})$; and $1.0 \mathrm{M} \mathrm{NaCl}$ treated cells for 120 minutes $(F, G)$ depicting time dependent effects of sodium chloride $(\mathrm{NaCl})$ on cytology of $Z$. bisporus cell. Scale bars, $2 \mu \mathrm{m}$. Electron micrograph of untreated $Z$. bisporus cells demonstrates normal structure of cell with Nucleus $(N)$, nucleolus $(N L)$ and cytoplasm appearing normal without abnormal changes (A). B and C demonstrated morphological features of early apoptosis; cell shrinkage, chromatin condensation (red arrow), clustering of dysfunctional mitochondria (encircled dotted), and cytoplasmic condensation (yellow arrow). D and E demonstrated the condensed cristae of mitochondria (MC), fragmented nuclei (FN), and cell

membrane disintegration as typical morphological features of intermediate apoptosis (orange arrow). $\mathrm{F}$ and $\mathrm{G}$ demonstrated morphological feature of late apoptosis; continuing blebbing (blue dotted arrow), and little cytoplasmic condensation.

\section{Discussion:}

Apoptosis is a well known mechanism of removing senescence and damaged cells as well as a means of adaptation in which yeast cell survives biotic and abiotic stresses. The biochemical changes involving ROS elevation, increased $\mathrm{Na}^{+} / \mathrm{K}^{+}$ratio and proteolysis are found to actively participate in PCD signal transduction. Overall resistance to ROS attack is mediated by a combined survival factors such as antioxidant defense system and cellular redox buffering capacity. However, in due course of their low levels, the yeast elicits an essential final response to oxidative stress, initiation of apoptosis.

As observed in other osmo- and halotolerant yeasts, this altruistic mechanism tends to clear off old, unhealthy cells, which enhances the chance of survival of healthier and younger clones in stressed cells $(20,21)$, thereby favorably explaining the affected cell growth and percent survival of $Z$. bisporus under different concentrations of $\mathrm{NaCl}$ (stress stimulator) for specified stress exposure intervals in a previous study (6). In the present study, as expected from serial dilution assay, the salt induced osmotic stress reduced 
and ultimately inhibited cell growth at highest observed concentration of $1.0 \mathrm{M} \mathrm{NaCl}$. Hence, the pattern of salt inhibition was exponential at this sub-lethal concentration in case of $Z$. bisporus. These results are in agreement with Silva-Graca and Lucas (4) for Candida versatillis, Sharma and Sharma (6) for $Z$. bisporus and Pribylova et al., (22) for Z. rouxii, where it was evident that cell survival reaches to near optimum values (as in pre-stress state) at the end of stress phase allowing growth restoration due to action of stress responsive factors.

The exponential phased cells in 60 minutes salt stress showed alterations and clustering of organelles. This finding explains the phenomenon of salinity induced PCD, previously reported in other halotolerant yeasts (23). Importantly, in TEM micrographs, nuclear condensation, which is one of the hallmark features of apoptosis, was visible soon after the onset of salt stress. Previous studies have suggested that primary salt induced ROS targets the unsaturated fatty acids leading to generation of wide variety of secondary reactive molecules such as autocatalytic lipid radicals and toxic lipid hydroperoxides $(24,25)$. Moreover, high levels of mitochondrial oxidative burst cause damage to membrane protein thiols via oxidation leading to decrease in membrane potential. These reactive protein and lipid carbonyls produced along the ROS cascade together with increased $\mathrm{Na}^{+} / \mathrm{K}^{+}$ratio accumulate during the chronological aging before the appearance of apoptosis. Accordingly, mitochondria contain several pro-apoptotic molecules that directly cleave nuclear DNA and activate cytosolic proteins (24). These factors along with several other pathways cause fragmentation, cross linking, and unfolding of protein backbone and nucleic acids, which condition the cells to undergo apoptosis to efficiently remove irreparably damaged oxidized cell components such as mitochondria.

According to Watson (26), chemostat studies in Saccharomyces cerevisiae revealed that $\mathrm{NaCl}$ stimulates apoptosis largely due to increased requirement for energy generating substrates involved in the cell maintenance, thus leading to simultaneous decrease in cell growth yield. Our study compared stressed yeast cells with that of control, showing distorted surface morphology with irregular cell wall and plasma membrane. The blabbing and rupturing of cell wall was more pronounced in cultures with higher stress time, particularly at the lethal span of 60 and 90 minutes. It was evident from the TEM micrographs that stressed yeast cells showed significant changes in chromatin distribution, and lacked definite cell membrane with cytoplasmic condensation along the membrane, which might be crucial in explaining the mechanism of salt toxicity. Possibly, salt enters the cell by bounding to specific surface transporters.

The chromatin was either unrecognizable (Figure 2: B) or sequestered towards the outer layer of nuclear envelope (Figure 2: C). The disruption of outer layers and intense chromatin condensation adjacent to nuclear envelope in association with multiple nuclear fragmentations have also been previously reported as an important mechanism of salt mediated inhibition of microorganisms (27-29). These apoptotic phenotypes were rescued over prolonged stress spans by diverting the ATP usage in accumulation of anti-ROS metabolites rather than towards growth, which likely cause regression of ROS accumulation and cell death $(6,9,10)$. Therefore, it confirms the postulated theory that salt induced ion toxicity prompted apoptosis as a component of adaptive response. This concludes that cell death might be a part of regulated adaptive process to ensure cell survival.

Altogether, salinity creates osmotic, ionic, and eventually ROS toxicity which are regulated mechanistically by haloadaptive responses such as compatible osmolyte production and accumulation (6), involvement of ion transporters across plasma membrane and cellular antioxidants like glutathione (9), modulation in cell wall properties, and apoptosis. Therefore, more of these research findings will be beneficial to food manufacturing industries since exhaustive information about food spoilage microbiota and their target foods, along with optimal growth conditions, can assist in choosing suitable natural preservatives, absolute processing techniques, and aids in improving safety issues, and controlling spoilage outbreaks. Additionally, the halophilic and halotolerant fungi are distinguished eukaryotic models for study of salt resistance owing to their characteristic growth rate in a wide range of $\mathrm{pH}$, osmotic and ionic concentrations, including toxic drugs $(29,30)$.

\section{Acknowledgement:}

The authors are grateful to the Indian Council of Medical Research, New Delhi, India for funding support through Grant number: 3/1/3/JRF-2013/HRD-134 (10040). 


\section{Disclosure statement:}

\section{No conflict of interest is declared}

\section{References:}

1. Kumar, S., Randhawa, A., Ganesan, K., et al. Draft genome sequence of salt tolerant yeast Debaryomyces hansenii var. hansenii MTCC 234. Eukaryotic Cell. 2012; 11: 961-962

2. Galeote, V., Bigey, F., Devillers, H., Neuveglise, C., and Dequin, S. Genome sequence of the food spoilage yeast Zygosaccharomyces bailli CLIB 213. Genome Announcement. 2013; 1(4): e00606-13

3. Louis, V. L., Despons, L., Friedrich, A., et al. Pichia sorbitophila, an interspecies yeast hybrid reveals early steps of genome resolution after polyploidization. G3 (Bethesda): 2012; 2 (2): 299311.

4. Silva-Graca, M., and Lucas, C. Physiological studies on long-term adaptation to salt stress in the extremely halotolerant yeast Candida versatilis CBS 4019 (syn. C. halophila). FEMS Yeast Res. 2003; 3: 247-260.

5. Ramos, J., Arino, J., and Sychrova, H. Alkalimetal-cation influx and efflux systems in nonconventional yeast species. FEMS Microbiol Lett. $2011 ; 317 ; 1-8$

6. Sharma, A., and Sharma, S, C. Physiological Basis for the Tolerance of Yeast Zygosaccharomyces bisporus to Salt Stress. HAYATI J Biosci. 2017; 24: $176-181$.

7. Logothetis, S., Walker, G., and Nerantzis, E. T. Effect of salt hyperosmotic stress on yeast cell viability. Proc Natl Acad Sci USA. 2007; 113: 271284

8. Farrugia, G., and Balzan, R. Oxidative Stress and Programmed Cell Death in Yeast. Front Oncol. 2012: 2: 64-85

9. Sharma, A, and Sharma, S. C. The importance of antioxidants and plasma membrane ion transporters which play role in cellular response against salt induced oxidative stress. Ecol Genet Genom. 2018; 9: 16-22.

10. Perrone, G. G., Tan, S. X., and Dawes, I. W. Reactive oxygen species and yeast apoptosis. BBA Mol Cell Res. 2008; 1783 (7): 1354-1368.

11. Carmona-Gutierrez, D., Eisenberg, T., Buttner, S., et al. Apoptosis in yeast: triggers, pathways, subroutines. Cell Death Differ. 2010; 17 (5): 763773.

12. Dupont, S., Beney, L., Ritt, J. F., et al. Lateral reorganization of plasma membrane is involved in the yeast resistance to severe dehydration. Biochim Biophy Acta. 2010; 1798: 975-985.

13. Mazzoni, C., Giannattasio, S., Winderickx, J., et al. Yeast Stress, Aging, and Death. Oxidat Med Cel Longe. 2013; doi: 10.1155/2013/684395.

14. Fesus, L., Davies, P. J., and Piacentini, M. Apoptosis: molecular mechanisms in programmed cell death. Eur J Cell Biol. 1991; 56: 170-177

15. Heath, M. C., and Ryerson, D. E. Cleavage of oligonucleosomal fragments during cell death induced by fungal infection or by abiotic treatment. Plant Cell. 1996; 8: 393-402

16. Navarrete, C., Siles, A., Martinez, J. L., et al. Oxidative stress sensitivity in Debaryomyces hansenii. FEMS Yeast Res. 2009; 9 (4): 582-590

17. Naylin, N., Taing, O. K., Hashinaga, F., et al. Antioxidant Activity of Sugar-Tolerant Yeast Zygosaccharomyces rouxii. Food Biotechnol. 2005; 19 (2): $107-120$

18. Kumar, S., and Gummadi, S. N. Osmotic adaptation in halotolerant yeast, Debaryomyces nepalensis NCYC 3413: role of osmolytes and cation transport. Extremophiles. 2009; 13: 793805

19. Wright, R. Transmission Electron Microscopy of Yeast. Microscop Res Techn. 2000; 51: 496- 510

20. Stratford, M., Steels, H., Novodvorska, M., et al. Extreme Osmotolerance and Halotolerance in Food-Relevant Yeasts and the Role of GlycerolDependent Cell Individuality. Front. Microbiol. 2018; 9: 32-38

21. Palma, M., Guerreiro, J. F., and Sa-Correia, I. Adaptive Response and Tolerance to Acetic Acid in Saccharomyces cerevisiae and Zygosaccharomyces bailii: A Physiological Genomics Perspective. Front Microbiol. 2018; 9: 1-16

22. Pribylova, L., Farkas, V., Slaninova, I., et al. Differences in osmotolerant and cell-wall properties of two Zygosaccharomyces rouxii strains. Folia Microbiol. 2007; 52 (3): 241-245.

23. Hohmann, S. Osmotic stress signaling and osmoadaptation in yeasts. Microbiol Mol Biol. Rev. 2002; 66 (2): 300-372.

24. Balzan, R., Sapienza, K., Galea, D. R., et al. Aspirin commits yeast cells to apoptosis depending on carbon source. Microbiology. 2004; 150: 109115

25. Joseph, B., and Jini, D. Salinity Induced Programmed Cell Death in Plants: Challenges and Opportunities for Salt-tolerant Plants. J Plant Sci. 2010; 5: 376-390.

26. Watson, T. G. Effects of Sodium Chloride on Steady-state Growth and Metabolism of Saccharomyces cerevisiae. J Gen Microbiol. 1970; 64: 91-99.

27. Kazemzadeh, L., Cvijovic, M., and Petranovic, D. Boolean model of yeast apoptosis as a tool to study yeast and human apoptotic regulations. Front Physiol. 2012; 3: 1-18.

28. Guaragnella, N., Zdralevic, M., Antonacci, L., Passarella, S., Marra, E., and Giannattasio, S. The role of mitochondria in yeast programmed cell death. Front Oncol. 2012; 2: 70

29. Falcone, C., and Mazzoni, C. External and internal triggers of cell death in yeast. Cell Mol Life Sci. 2016; 73: 2237-2250

30. Bohnert, H. J., Golldack, D., Ishitani, M., et al. Salt tolerance engineering requires multiple gene transfers. Ann N Y Acad Sci. 1996; 792: 115-125 